\title{
Pengaruh Kepuasan Pengguna Sistem Terhadap Kinerja PembelajaranDaring Dengan Biaya Sebagai Moderasi
}

\author{
Raymundo Patria Hayu Sasmita ${ }^{1}$, Ignatius Novianto Hariwibowo ${ }^{2}$ \\ ${ }^{1}$ Prodi Akuntansi, Universitas Atma Jaya Yogyakarta, Indonesia. \\ Email: raymundo.patria@uajy.ac.id \\ ${ }^{2}$ Prodi Akuntansi, Universitas Atma Jaya Yogyakarta, Indonesia. \\ Email: novianto.wibowo@uajy.ac.id
}

\begin{abstract}
Abstrak
Wabah covid-19 telah memaksa pendidikan di Indonesia untuk menerapkan sistem pembelajaran daring. Perubahan ini menimbulkan fenomena keluhan masyarakat terhadap besarnya biaya belajar daring. Hal ini menimbulkan ketidakpuasan masyarakat terhadap sistem belajar daring. Oleh karena itu, penelitian ini dilakukan untuk menguji faktor yang mempengaruhi kinerja pembelajaran dalam sistem pembelajaran daring dengan biaya sebagai moderasi. Penelitian ini mengembangkan kepuasan pengguna sistem sebagai variabel mediasi dan pembelajaran, sistem, pengajar sebagai variabel independen. Penelitian dilakukan pada mahasiswa akuntansi yang sedang mengambil mata kuliah Sistem Informasi Akuntansi dan Analisa Perancangan Sistem. Data diperoleh dengan mendistribusikan kuesioner secara daring kepada 185 mahasiswa. Data yang diperoleh di oleh menggunakan pendekatan Partial Least Square (PLS), dengan menggunakan software WarpPLS 6.0. Hasil penelitian ini menunjukkan bahwa proses pembelajaran yang jelas dan sistematis akan meningkatkan kepuasan pengguna dan berdampak pada kinerja pembelajaran yang baik. Sedangkan, besarnya biaya belajar daring tidak mempengaruhi kinerja pembelajaran.
\end{abstract}

Kata Kunci: Pembelajaran daring; sistem; biaya; pembelajaran

\section{The Effect of System User Satisfaction on Online Learning Performance with Cost as Moderation Abstract}

The covid-19 outbreak has forced education in Indonesia to implement an online learning system. This change has led to the phenomenon of public complaints about the high cost of studying online. This raises public dissatisfaction with the online learning system. Therefore, this study was conducted to examine the factors that influence learning performance in an online learning system with cost as moderation. This study develops system user satisfaction as a mediating variable and learning, system, teacher as independent variables. The research was conducted on accounting students who were taking the Accounting Information Systems course and System Design Analysis. The data were obtained by distributing questionnaires online to 185 students. The data obtained by using the Partial Least Square (PLS) approach, using the WarpPLS 6.0 software. The results of this study indicate that a clear and systematic learning process will increase user satisfaction and have an impact on good learning performance. Meanwhile, the amount of online learning costs does not affect learning performance.

Keywords: online learning; system; cost; learning

DOI: $10.25273 /$ inventory.vxix.7408

Copyright (C) 2021 Penulis

Sume rights reserved. 


\section{Pendahuluan}

Aktivitas pembelajaran secara daring (e-learning) bukanlah sesuatu hal yang baru di Indonesia. Perkembangan teknologi komunikasi telah membawa perubahan terhadap dunia pendidikan di Indonesia. Walaupun tampaknya sistem pembelajaran daring menawarkan keuntungan (Kim, 2011), namun belum semua institusi pendidikan menerapkan sistem pembelajaran daring ini secara penuh. Kondisi berubah di saat terjadi wabah pandemik covid- 19 yang melanda di banyak negara. Sebagai dampaknya, institusi pendidikan tidak dapat menjalankan proses belajar mengajar secara tatap muka. Dalam hal ini, pembelajaran daring merupakan solusi yang harus dipilih oleh institusi pendidikan untuk tetap melaksanakan tanggung jawab institusi pendidikan. Kondisi yang memaksa institusi pendidikan membuat institusi berusaha sedemikian rupa untuk dapat menyelenggarakan pembelajaran daring yang efektif sehingga dapat membuat siswa tetap puas terhadap layanan yang diberikan institusi. Khususnya dalam pendidikan tinggi, perguruan tinggi dituntut untuk dapat memberikan proses yang baik melalui pembelajaran daring (Lim dan Lim, 2004; Moon dan Nam, 2007).

Dalam penyelenggaraan pembelajaran daring, banyak peneliti telah melakukan penelitian untuk menjelaskan faktor yang dapat meningkatkan efektivitas dan kepuasan siswa pembelajaran daring. Beberapa penelitian menunjukkan bahwa kualitas pembelajaran daring didukung oleh sistem (Kwon dan Noh, 2015; Chopra et al., 2019; Chien, 2012). Secara khusus, penelitian Chopra et al. (2019) menunjukkan bahwa kualitas sistem dan kualitas layanan sistem lebih mempengaruhi kepuasan pengguna sistem pembelajaran daring dari pada kualitas informasi dalam sistem. Hal ini menunjukkan bahwa peran teknis teknologi mempengaruhi siswa dalam mengikuti pembelajaran daring. Selain itu, pembelajaran daring, secara teknis, menawarkan proses yang lebih efisien yang akan meningkatkan kepuasan siswa dan akhirnya meningkatkan kinerja pembelajaran.

Walaupun demikian, beberapa survei menunjukkan bahwa banyak siswa yang tidak puas dengan berlakunya pembelajaran daring (www.rmoljateng.com, 2020). Hal ini disebabkan karena biaya yang tinggi yang harus ditanggung oleh siswa. Kondisi ini didukung dengan penelitian Taplin et al. (2013). Penelitian Taplin et al. (2013) menunjukkan bahwa ada batasan biaya yang dapat diterima oleh siswa untuk dapat terlibat aktif dalam proses pembelajaran daring. Penelitian Dada et al. (2019) menjelaskan bahwa beberapa metode pembelajaran daring yang efektif memiliki konsekuensi biaya yang tinggi. Konsekuensi biaya ini berpotensi untuk mempengaruhi proses belajar mengajar sehingga dapat berpengaruh pada efektivitas pembelajaran bagi siswa. Adanya faktor biaya yang dapat mempengaruhi efektivitas proses belajar belum dijelaskan dalam penelitian Kwon dan Noh, (2015); Chopraet al. (2019). Dengan demikian penelitian ini dilakukan untuk menjelaskan pengaruh biaya terhadap proses pembelajaran daring yang belum dijelaskan pada penelitian Kwon dan Noh (2015). Pengaruh biaya terhadap proses belajar penting untuk dapat dijelaskan untuk membangun proses pembelajaran daring yang efisien dan efektif.

Untuk menguji pengaruh biaya pada proses pembelajaran daring (online), penelitian ini akan dilakukan secara khusus pada mahasiswa akuntansi yang sedang mengambil mata kuliah Sistem Informasi Akuntansi dan Analisa Perancangan Sistem. Mahasiswa di kedua mata kuliah ini dipilih karena mereka, secara konsep, mempelajari peran teknologi dalam suatu proses bisnis. Dengan demikian, mereka memahami kriteria teknologi yang sesuai untuk mendukung proses pembelajaran. Pemilihan mahasiswa pada mata kuliah yang khusus diperlukan untuk dapat menemukan pola belajar daring yang lebih sesuai dengan konteksnya (Chopra et al., 2019). Secara umum banyak penelitian pembelajaran daring melibatkan banyak siswa dengan berbagai latar belakang. Dimungkinkan bahwa perbedaan latar belakang ilmu membutuhkan bentuk pembelajaran daring yang berbeda. Dengan demikian pembelajaran daring dengan karakteristik tertentu diperlukan untuk menemukan bentuk pembelajaran daring yang sesuai. Hasil penelitian ini dapat membantu untuk desain aktivitas pembelajaran yang efektif, namun dengan biaya aktivitas yang lebih terukur untuk pembelajaran daring sehingga proses belajar menjadi lebih efisien dari segi biaya. 


\section{Metode Penelitian}

Jenis penelitian ini adalah penelitian kuantitatif dengan obyek penelitian ini adalah mahasiswa, pada suatu universitas di Yogyakarta, sebagai salah satu universitas yang menggunakan sistem pembelajaran daring. Sampel penelitian ini ditentukan dengan purposive sampling. Pada penelitian ini mahasiswa akuntansi yang sedang mengambil mata kuliah Sistem Informasi Akuntansi dan Analisa Perancangan Sistem dipilih pada semester Genap 2019/2020 sebagai responden. Sampel ini dipilih karena mahasiswa pada kelas ini mempelajari peran teknologi dalam proses bisnis sehingga dapat mengevaluasi kinerja sistem. Mahasiswa pada semester tersebut juga mengalami dua metode pembelajaran yang berbeda, yaitu luring (offline) secara penuh dan daring (online) secara penuh akibat pandemik covid-19. Dengan demikian, mereka akan dapat menghasilkan penilaian terhadap proses pembelajaran secara menyeluruh. Data dalam penelitian ini diperoleh dengan cara membagikan kuisioner kepada mahasiswa yang sesuai dengan kriteria sampel.

\section{Definisi Operasional Dan Pengukuran Variabel}

Penelitian ini menggunakan lima variabel. Variabel independen adalah pembelajaran, sistem, dan pengajar. Variabel mediasi pada penelitian ini adalah kepuasan pengguna sistem. Variabel dependen pada penelitian ini adalah kinerja pembelajaran. Variabel moderasi adalah biaya. Variabel pembelajaran pada penelitian ini adalah suatu bentuk aktivitas belajar mengajar yang sistematis untuk mencapai capaian pembelajaran. Pengertian ini mengacu pada penelitian Kwon dan Noh (2015). Variabel sistem pada penelitian ini adalah sistem pembelajaran daring yang didasarkan pada teknologi informasi yang memfasilitasi proses pembelajaran daring. Pengertian ini mengacu pada penelitian Chopra (2019). Variabel pengajar pada penelitian ini adalah bentuk peran pengajar (dosen) atau kemampuan pengajar dalam memberikan pengajaran selama proses pembelajaran daring. Pengertian ini mengacu pada penelitian (Kwon dan Noh, 2015). Variabel kepuasan pengguna sistem pada penelitianini merupakan bentuk pengalaman positif pengguna sistem saat menggunakan sistem pembelajaran daring (Kwon dan Noh, 2015). Variabel kinerja pembelajaran dalam penelitian ini adalah suatu hasil yang diperoleh siswa dari proses pembelajaran (Wei et al., 2012).

Pertanyaan pada variabel dalam penelitian ini diukur dengan menggunakan skala interval, yaitu dengan likert 1 sampai 5. Nilai 1 menunjukkan sangat tidak setuju, sedangkan nilai 5 menunjukkan sangat setuju. Namun, secara khusus, variabel biaya pada penelitian ini merupakan bentuk penilaian besarnya biaya pembelajaran daring yang dikeluarkan mahasiswa. Besarnya biaya yang dikeluarkan oleh mahasiswa bisa sangat beragam. Di sisi lain, tidak ada ukuran pasti mengenai pengeluaran untuk pembelian kuota internet. Oleh karena itu pengukuran variabel biaya akan menggunakan skala ordinal yang didasarkan pada penilaian masing-masing mahasiswa dengan kriteria, yaitu: rendah, sedang/cukup, dan tinggi. Indikator pengukuran variabel tersebut dapat dilihat pada tabel 1.

Tabel 1. Pengukuran Variabel

\begin{tabular}{|c|c|c|c|}
\hline Variabel & Elemen & & Sumber \\
\hline \multirow[t]{2}{*}{ Pembelajaran } & 1. Sistematis & $\begin{array}{l}\text { 1. Pembelajaran online teratur } \\
\text { secara sistematis. } \\
\text { 2. Pembelajaran online mudah } \\
\text { dimengerti. }\end{array}$ & $\begin{array}{l}\text { Kwon dan Noh } \\
\text { (2015) }\end{array}$ \\
\hline & 2. Kesesuaian & $\begin{array}{l}\text { 1. Aktivitas pembelajaran online. } \\
\text { sesuai dengan tujuan } \\
\text { pembelajaran. } \\
\text { 2. Pembelajaran online memotivasi } \\
\text { untuk belajar. } \\
\text { 3. Pembelajaran online sesuai } \\
\text { untuk ujian tengah atau akhir } \\
\text { semester. }\end{array}$ & \\
\hline
\end{tabular}




\begin{tabular}{|c|c|c|c|}
\hline \multirow[t]{2}{*}{ Sistem } & 1. Stabil & $\begin{array}{l}\text { 1. Selama pembelajaran online } \\
\text { internet tidak terganggu. } \\
\text { 2. Proses pembelajaran online } \\
\text { dapat terlaksana tanpa masalah. } \\
\text { 3. Pembelajaran online pada } \\
\text { gadget dapat dilakukan tanpa } \\
\text { masalah. }\end{array}$ & \multirow[t]{2}{*}{$\begin{array}{l}\text { Chopra et al. } \\
(2019)\end{array}$} \\
\hline & 2. Kemudahan & $\begin{array}{l}\text { 1. Kehadiran dapat tercatat tanpa } \\
\text { ada kesalahan. } \\
\text { 2. Mengungah tugas sangat } \\
\text { terbantu dengan sistem } \\
\text { manajemen pembelajaran } \\
\text { online. }\end{array}$ & \\
\hline \multirow[t]{3}{*}{ Pengajar } & 1. Antusias & $\begin{array}{l}\text { 1. Dosen sangat antusias } \\
\text { menggunakan pembelajaran } \\
\text { online. }\end{array}$ & \multirow[t]{3}{*}{$\begin{array}{l}\text { Kwon dan Noh } \\
(2015)\end{array}$} \\
\hline & 2. Respon & $\begin{array}{l}\text { 1. Dosen memberikan tanggapan } \\
\text { terhadap aktivitas pembelajaran } \\
\text { online dengan waktu yang } \\
\text { sesuai. } \\
\text { 2. Proses pembelajaran dan materi } \\
\text { dosen sangat menolong untuk } \\
\text { proses pembelajaran. }\end{array}$ & \\
\hline & $\begin{array}{l}\text { 3. Kesesuaian } \\
\text { materi }\end{array}$ & $\begin{array}{l}\text { 1. Dosen memberikan tugas yang } \\
\text { sesuai. }\end{array}$ & \\
\hline \multirow[t]{3}{*}{$\begin{array}{l}\text { Kepuasan } \\
\text { pengguna }\end{array}$} & $\begin{array}{l}\text { 1. Kesesuaian } \\
\text { harapan }\end{array}$ & $\begin{array}{l}\text { 1. Pembelajaran online secara } \\
\text { keseluruhan sesuai dengan studi } \\
\text { saya. } \\
\text { 2. Pembelajaran online secara } \\
\text { keseluruhan sesuai untuk } \\
\text { meningkatkan kemampuan } \\
\text { saya. } \\
\text { Saya akan mengambil mata } \\
\text { kuliah lanjutan secara online }\end{array}$ & \multirow[t]{3}{*}{$\begin{array}{l}\text { Kwon dan Noh } \\
\text { (2015) }\end{array}$} \\
\hline & 2. Keberlanjutan & $\begin{array}{l}\text { 1. Saya akan merekomendasikan } \\
\text { pembelajaran online kepada } \\
\text { yang lain. }\end{array}$ & \\
\hline & 3. Kepuasan & $\begin{array}{l}\text { 1. Secara keseluruhan, saya puas } \\
\text { terhadap pembelajaran online } \\
(\text { e-learning }) \text {. }\end{array}$ & \\
\hline
\end{tabular}

Kinerja $1 . \quad$ Capaian 1. Saya selalu menyelesaikan tugas Wei et al. 


\begin{tabular}{|c|c|c|c|c|}
\hline pembelajaran & penge & huan & $\begin{array}{l}\text { dalam pembelajaran online. } \\
\text { 2. Saya mencapai tujuan } \\
\text { pembelajaran dengan } \\
\text { pembelajaran online } \\
\text { 3. Saya telah belajar pengetahuan } \\
\text { berharga dalam pembelajaran } \\
\text { online }\end{array}$ & (2012) \\
\hline Biaya & $\begin{array}{l}\text { Persepsi } \\
\text { biaya }\end{array}$ & besaran & $\begin{array}{l}\text { 1. Rendah. } \\
\text { 2. Sedang/cukup }\end{array}$ & $\begin{array}{l}\text { Taplin et al., } \\
2013\end{array}$ \\
\hline
\end{tabular}

Pengujian hipotesis pada penelitian ini menggunakan Partial Least Square (PLS). RegresiPLS merupakan bagian dari Strucktural Equation Model (SEM) yang sesuai untuk dapat memprediksi hubungan dalam model yang kompleks. Analisa akan dilakukan dengan menggunakan WarpPLS 6.0. Sebelum dilakukan uji hipotesis akan dilakukan uji reliabilitas dan validitas pada instrumen penelitian untuk menguji kelayakan instrumen. Uji reliabilitas menggunakan nilai Cronbach's alpha dan composite reliability dengan nilai diterima di atas 0.7. Uji validitas akan menggunakan nilai dari cross loading factor dan average variance extracted (AVE) dengan nilai masing-masing diatas 0.7 dan 0.5. Pengujian goodness of fit menggunakan APC (average path coefficient), ARS (average R-squared), AVIF (average variance inflation factor), dan AFVIF (averege full collinearity variance inflation factor). APC and ARS signifikan pada nilai p di bawah 0.05. Nilai AVIF di bawah 5 dan nilai AFVIF (averege full collinearity variance inflation factor) di bawah 3.3. Hipotesis akan diterima jika nilai $\mathrm{p}$ di bawah 0.05 .

\section{Hasil Dan Pembahasan}

\section{Deskripsi Responden}

Kuesioner penelitian didistribusikan kepada semua mahasiswa yang sedang mengambil mata kuliah Sistem Informasi Akuntansi dan Analisa Perancangan Sistem dengan menggunakan $M S$ Form. Jumlah kuesioner yang dibagikan adalah 185. Kuesioner yang kembali dan diolah adalah 165. Berikut ini adalah ringkasan deskripsi responden. Secara lengkap deskriptif responden dapat dilihat pada tabel 2 berikut ini:

Tabel 2. Deskriptif Responden

\begin{tabular}{lr}
\hline \multicolumn{1}{c}{ Keterangan } & Jumlah \\
\hline Jenis kelamin & 46 \\
Pria & 119 \\
Wanita & \\
Metode pembelajaran yang disukai & 108 \\
Tatap muka / luring & 57 \\
Online / daring & \\
Metode pembelajaran daring yang disukai & 89 \\
asynchronous & 76 \\
synchronous & \\
Media pembelajaran daring yang disukai & 102 \\
MS Teams & 45 \\
Moodel & 6 \\
Zoom & 12
\end{tabular}




\section{Penilaian besarnya biaya pembelajaran daring $($ Cost $)$}

\begin{tabular}{lr}
\hline Rendah & 11 \\
Sedang / cukup & 126 \\
Tinggi & 28
\end{tabular}

Rata-rata penilaian responden terhadap variabel

\begin{tabular}{lr} 
Kepuasan (CSF) & 3 \\
Pembelajaran (LF) & 3,1 \\
Sistem (SF) & 2,5 \\
Pengajar (TF) & 3,4 \\
Kinerja pembelajaran (LP) & 3,4 \\
\hline
\end{tabular}

Sumber: Kuesioner diolah 2020

Hasil olah data deskriptif responden pada tabel 2 menunjukkan bahwa sebagian besar responden (63\% responden) lebih menyukai belajar secara tatap muka dari pada belajar secara daring. Kondisi ini mengindikasikan banyak mahasiswa atau siswa lebih memilih untuk belajar secara luring. Hal ini dimungkinkan karena keuntungan dari kuliah tatap muka adalah interaksi langsung dengan sesama mahasiswa yang tidak mudah dilakukan saat belajar daring. Walaupun demikian, pada saat belajar secara daring, mahasiswa lebih menyukai metode asynchronous atau tanpa video conference (54\% responden) dibandingkan synchronous atau dengan video conference. Kondisi ini dimungkinkan karena sifat belajar secara asynchronous lebih fleksibel. Mahasiswa dapat belajar kapan saja dan di mana saja. Hasil kuesioner menunjukkan bahwa media yang disukai oleh mahasiswa untuk belajar secara daring adalah MS Teams (62\%) dan Moodle. Dengan demikian, ke dua media ini dapat dipilih untuk digunakan pada pembelajaran daring selanjutnya. Hasil yang cukup mengejutkan adalah penilaian mahasiswa terkait dengan besarnya biaya belajar daring. Sebagian besar mahasiswa menilai biaya belajar daring tidak terlalu tinggi atau sedang (76\% responden). Kondisi ini berbeda dengan fenomena yang menunjukkan bahwa banyak orang mengeluhkan besarnya biaya belajar daring. Hal ini mungkin disebabkan juga karena penelitian dilakukan pada salah satu universitas swasta besar di Yogyakarta. Kondisi yang berbeda mungkin dapat terjadi pada universitas lain di luar kota besar.

Hasil penilaian rata-rata terhadap variabel yang diajukan pada penelitian ini menunjukkan bahwa kepuasan mahasiswa belum maksimal (rata-rata 3 atau cukup) terhadap proses pembelajaran daring yang dilakukan. Permasalahan tampak dari hasil rata-rata penilaian terhadap sistem pembelajaran daring yang dilakukan selama ini yaitu: 2,5. Nilai rata-rata tersebut menunjukkan bahwa mahasiswa menilai sistem tidak cukup mengakomodasi kebutuhan belajar. Kondisi ini dimungkinkan karena penerapan pembelajaran daring yang sangat cepat akibat pandemik yang dengan cepat menyebar. Masalah ini menyebabkan kurang siapnya konsep dan infrastruktur pembelajaran daring.

\section{Uji Validitas dan Reliabilitas}

Penilaian uji reliabilitas pada penelitian ini menggunakan cronbach's alpha dan composite reliability dengan nilai diterima di atas 0.7 . Hasil olah data dengan WarpPLS 6.0 menghasilkan nilai coefficients cronbach's alpha dan composite reliability sebagai berikut:

Tabel 3. Uji Reliabilitas

\begin{tabular}{lcc}
\hline & $\begin{array}{c}\text { Composite reliability } \\
\text { coefficients }\end{array}$ & $\begin{array}{c}\text { Cronbach's alpha } \\
\text { coefficients }\end{array}$ \\
\hline CSF & 0.885 & 0.837 \\
LF & 0.854 & 0.785
\end{tabular}




\begin{tabular}{lll} 
SF & 0.876 & 0.818 \\
$\mathrm{TF}$ & 0.850 & 0.779 \\
$\mathrm{LP}$ & 0.809 & 0.645 \\
Cost & 1.000 & 1.000 \\
Cost*CS & 0.881 & 0.829 \\
\hline
\end{tabular}

Sumber: Data Diolah 2020

Catatan: CSF: kepuasan, LF: pembelajaran; SF: sistem; TF: pengajar; LP: kinerja pembelajaran; Cost: biaya yang dikeluarkan untuk pembelajaran daring.

Hasil uji reliabilitas pada tabel 3 menunjukkan bahwa semua variabel telah memenuhi kriteria reliabilitas karena semua nilai cronbach's alpha dan composite reliability telah di atas 0.7.

Uji validitas pada penelitian menggunakan nilai dari cross loading factor dan average variance extracted (AVE). Variabel dikatakan valid jika dengan nilai masing-masing indikator dalam cross loading factor memiliki nilai sama dengan atau di atas 0.7. Sedangkan, nilai untuk AVE sama dengan atau di atas 0.5. Hasil oleh data WarpPLS 6.0 adalah sebagai berikut:

Tabel 4. Uji Validitas: Cross Loading Fanctor

\begin{tabular}{|c|c|c|c|c|c|c|c|}
\hline & $\mathrm{CSF}$ & $\mathrm{LF}$ & SF & TF & LP & Cost & Cost*CS \\
\hline CSF1 & 0.824 & -0.089 & 0.050 & 0.181 & -0.101 & 0.063 & 0.030 \\
\hline CSF2 & 0.809 & 0.160 & 0.134 & -0.074 & 0.006 & 0.094 & -0.078 \\
\hline CSF3 & 0.726 & -0.226 & -0.164 & 0.188 & 0.083 & -0.076 & 0.121 \\
\hline CSF4 & 0.836 & 0.126 & -0.089 & 0.025 & -0.034 & -0.059 & -0.062 \\
\hline CSF5 & 0.694 & 0.004 & 0.062 & -0.356 & 0.067 & -0.034 & 0.004 \\
\hline LF1 & 0.060 & 0.733 & -0.087 & 0.171 & 0.067 & -0.120 & 0.012 \\
\hline LF2 & 0.074 & 0.806 & 0.065 & -0.098 & -0.023 & 0.183 & -0.041 \\
\hline LF3 & -0.175 & 0.769 & -0.046 & 0.017 & 0.001 & 0.028 & 0.031 \\
\hline LF4 & 0.040 & 0.797 & 0.058 & -0.074 & -0.040 & -0.101 & 0.000 \\
\hline SF1 & -0.054 & -0.025 & 0.884 & -0.013 & -0.044 & -0.106 & 0.017 \\
\hline $\mathrm{SF} 2$ & 0.079 & 0.068 & 0.935 & -0.015 & -0.054 & 0.060 & -0.008 \\
\hline SF3 & -0.028 & -0.045 & 0.916 & 0.027 & 0.097 & 0.041 & -0.008 \\
\hline TF1 & -0.083 & 0.330 & 0.146 & 0.716 & -0.314 & 0.172 & -0.136 \\
\hline TF2 & -0.098 & -0.023 & -0.037 & 0.704 & 0.043 & 0.021 & 0.067 \\
\hline TF3 & 0.183 & -0.437 & -0.034 & 0.817 & 0.067 & -0.143 & 0.121 \\
\hline TF4 & -0.026 & 0.167 & -0.061 & 0.820 & 0.171 & -0.025 & -0.059 \\
\hline LP1 & -0.271 & -0.069 & -0.180 & -0.102 & 0.707 & -0.127 & 0.031 \\
\hline LP2 & 0.317 & -0.007 & 0.096 & -0.000 & 0.813 & -0.006 & -0.024 \\
\hline LP3 & -0.086 & 0.071 & 0.063 & 0.093 & 0.773 & 0.122 & -0.003 \\
\hline B & -0.000 & 0.000 & 0.000 & 0.000 & 0.000 & 1.000 & -0.000 \\
\hline $\mathrm{B} * \mathrm{CSF} 1$ & 0.043 & -0.153 & -0.074 & 0.022 & 0.184 & 0.099 & 0.786 \\
\hline $\mathrm{B} * \mathrm{CSF} 2$ & -0.012 & 0.059 & 0.007 & 0.049 & -0.140 & -0.072 & 0.853 \\
\hline $\mathrm{B} * \mathrm{CSF} 3$ & 0.074 & -0.236 & 0.129 & 0.310 & -0.032 & 0.276 & 0.637 \\
\hline B*CSF4 & -0.121 & 0.192 & -0.001 & -0.172 & -0.003 & -0.182 & 0.873 \\
\hline $\mathrm{B} * \mathrm{CSF} 5$ & 0.050 & 0.076 & -0.042 & -0.152 & -0.003 & -0.048 & 0.700 \\
\hline
\end{tabular}

Tabel 4 menunjukkan bahwa semua variabel penelitian telah memenuhi kriteria uji validitas, yaitu nilai cross loading factor di atas 0.7. Walaupun demikian, hasil uji tersebut diperoleh setelah indikator LF5, SF4, SF5, dan TF5 dihapus karena memiliki nilai di bawah 0.7. Dalam uji cross loading 
tersebut, diketahui bahwa nilai loading factor untuk cost atau biaya pembelajaran daring adalah 1 . Hal ini disebabkan karena variabel tersebut hanya memiliki satu indikator. Di samping itu, validasi nilai dari nilai loading factor pada tabel 4, ada yang menunjukkan nilai 0.637 (B*CSF3). Nilai tersebut tetap dipertahankan karena nilai tersebut menunjukkan nilai moderasi. Solihin dan Ratmono (2013) menjelaskan bahwa nilai loading factor 0.6 masih dimungkinkan untuk diterima pada saat menguji konsep baru. Halini didukung juga dengan nilai AVE di atas 0.5. Dengan demikian, semua variabel memenuhi kriteria validitas.

Tabel 5. Average variances extracted (AVE)

\begin{tabular}{ccccccc}
\hline CSF & LF & SF & TF & LP & Cost & Cost*CS \\
\hline 0.608 & 0.603 & 0.832 & 0.587 & 0.586 & 1.000 & 0.600 \\
\hline
\end{tabular}

\section{Uji Goodness of Fit}

Uji goodness of fit dilakukan untuk menilai kelayakan model yang di bangun dalam penelitian ini. Nilai goodness of fit pada penelitian ini menggunakan nilai dari APC (average path coefficient), ARS (average R-squared), AVIF (average variance inflation factor), dan AFVIF (averege full collinearity variance inflation factor). Hasil analisa WarpPLS 6.0 secara otomatis menghasilkan nilai tersebut dengan indikatornya.

Tabel 6. Uji Goodness of Fit

\begin{tabular}{lcc}
\hline \multicolumn{1}{c}{ Indikator } & Nilai & Ideal \\
\hline APC & $\mathrm{P}<0,001$ & $<0.05$ \\
ARS & $\mathrm{P}<0,001$ & $<0.05$ \\
AVIF & 1,343 & $<3.3$ \\
AFVIF & 1,7 & $<3.3$ \\
\hline
\end{tabular}

Hasil tabel 6 menunjukkan bahwa semua kriteria Goodness of Fit telah terpenuhi. Dengan demikian variabel yang disusun dalam model penelitian ini sesudah sesuai.

\section{Uji Hipotesis}

Uji hipotesis pada penelitian ini menggunakan tingkat signifikansi 5\%. Hipotesis diterima jika nilai p di bawah 5\% atau 0.05. Berikut ini adalah hasil olah data WarpPLS 6.0:

Tabel 7. Uji Hipotesis

\begin{tabular}{lccr}
\hline \multicolumn{1}{c}{ Hipotesis } & Path coefficients & P values & Hasil \\
\hline H1 LF*CSF & 0.645 & $<0.001$ & Terdukung \\
H2 SF*CSF & 0.047 & 0.271 & Tidak terdukung \\
H3 TF*CSF & 0.096 & 0.105 & Tidak terdukung \\
H4 CSF*LP & 0.485 & $<0.001$ & Terdukung \\
H5 Cost*CSF*LP & -0.004 & 0.477 & Tidak terdukung \\
\hline
\end{tabular}

Hasil uji hipotesis menunjukkan bahwa $\mathrm{H} 1$ dan $\mathrm{H} 4$ terdukung, sedangkan $\mathrm{H} 2$, H3, dan $\mathrm{H} 5$ tidak terdukung. Dengan demikian, hasil penelitian ini menjelaskan bahwa faktor atau variabel pembelajaran berpengaruh positif terhadap kepuasan pengguna sistem pembelajaran daring. Hal Sistem dan pengajar tidak berpengaruh pada kepuasan pembelajaran daring. Kepuasan pengguna sistem berpengaruh pada kinerja pembelajaran. Hasil penelitian ini juga menunjukkan bahwa biaya tidak mempengaruhi hubungan kepuasan terhadap kinerja pembelajaran. 


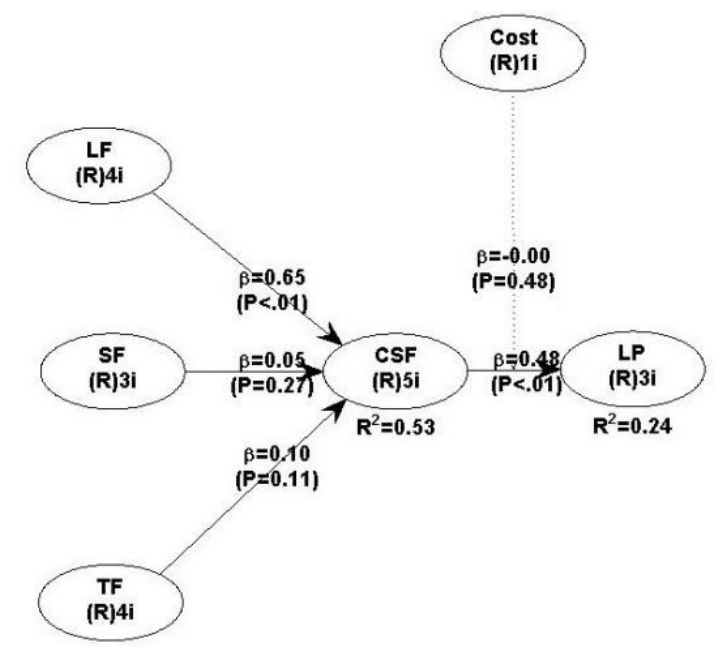

Gambar 2. Hasil Uji Model

\section{Pembahasan}

Hasil penelitian ini menunjukkan bahwa faktor yang mempengaruhi kepuasan pengguna sistem pembelajaran daring adalah proses pembelajaran. Hasil ini menjelaskan bahwa konsep pembelajaran yang sistematis dan jelas akan membuat mahasiswa dapat mengikuti prosespembelajaran dengan baik. Kejelasan proses pembelajaran akan meningkatkan kepuasan mahasiswa dalam mengikuti proses pembelajaran daring. Proses pembelajaran yang jelas akan membantu mahasiswa dapat mengikuti proses pembelajaran dengan baik seperti pada pembelajaran tatap muka (Simonson et al., 2012). Hasil penelitian ini didukung dengan penelitian Chopra et al. (2019) yang menjelaskan bahwa proses aktivitas dalam sistem yang sistematis akan meningkatkan kepuasan pengguna sistem (Kim, 2009). Pengaruh pembelajaran terhadap kepuasan pada penelitian ini secara tidak langsung juga menunjukkan bahwa konsep pembelajaran yang dilakukan pada semester genap 2019/2020 pada mata kuliah Sistem Informasi Akuntansi dan Analisa Perancangan Sistem telah disusun denganjelas dengan capaian yang jelas.

Hasil selanjutnya pada penelitian ini adalah faktor sistem dan pengajar tidak mempengaruhi kepuasan pengguna sistem. Hasil ini bertentangan dengan penelitian Kwon dan Noh (2015). Penelitian Kwon dan Noh (2015) dan Chopra et al. (2019) yang menunjukkan bahwa sistem merupakan faktor yang paling berpengaruh signifikan untuk meningkatkan kepuasan pengguna pembelajaran daring. Kondisi ini dimungkinkan karena sifat penerapan pembelajaran daring yang tergesa-gesa menimbulkan infrastruktur yang belum siap secara penuh untuk dapat mengakomodasi harapan pengguna sistem dalam pembelajaran daring. Masalah ini didukung dengan hasil deskriptif responden yang menunjukkan rata-rata mahasiswa menilai kondisi sistem yang tidak baik. Hipotesis 3 yang tidak terdukung menunjukkan juga bahwa hasil ini tidak mendukung penelitian Burgstahler (1997) yang menjelaskan bahwa peran pengajar akan mendukung kepuasan pengguna sistem pembelajaran daring. Namun demikian, penelitian Kwon dan Noh (2015) juga menunjukkan bahwa pengajar bukan faktor yang secara signifikan mempengaruhi kepuasan penggunaan sistem. Hasil ini secara tidak langsung menunjukkan bahwa sistem dan pengajar belum siap di saat penerapan pembelajaran daring diterapkan. Ketidaksiapan ini membuat mahasiswa tidak puas dengan sistem pembelajaran daring yang diterapkan.

Hipotesis 4 dalam penelitian ini terdukung. Hasil ini menunjukkan bahwa kepuasan pengguna sistem pembelajaran daring akan meningkatkan kinerja pembelajaran. Hasil ini sesuai dengan penelitian Kwon dan Noh (2015); Chopra et al. (2019); Lin dan Chen (2012), Liaw dan Huang (2014). Penelitian tersebut menegaskan kepuasan berperan penting dalam keberhasilan proses pembelajaran daring. Secara tidak langsung, temuan ini menunjukkan bahwa mahasiswa dapat mengikuti proses pembelajaran secara daring walaupun terdapat kekurangan dalam sistem pendukung 
dan pengajar yang belum siap.

Hipotesis 5 menunjukkan bahwa besarnya biaya tidak mempengaruhi capaian hasil pembelajaran. Walaupun demikian, biaya menunjukkan arah pengaruh yang negatif, yaitu koefisien -0.004. Nilai koefisien ini berarti bahwa biaya memang berpotensi untuk menurunkan kepuasan dan kinerja pembelajaran yang berakibat pada menurunnya kinerja pembelajaran. Variabel biaya merupakan variabel yang bersifat elastis. Artinya, ada batasan nominal tertentu yang rela dibayarkan oleh mahasiswa dalam mengikuti pembelajaran daring (Taplin et al., 2013). Namun pada penelitian ini, besarnya biaya pembelajaran daring, secara mayoritas, masih dapat diterima oleh mahasiswa. Hal ini didukung dengan hasil deskripsi responden yang secara mayoritas menilai bahwa biaya pembelajaran daring adalah sedang/cukup.

\section{Kesimpulan Dan Saran}

Penelitian ini dilakukan untuk menguji faktor yang mempengaruhi kinerja pembelajaran dalam sistem pembelajaran daring yang diterapkan secara mendadak. Hasil penelitian ini menunjukkan bahwa tidak semua hipotesis penelitian terdukung. Penelitian ini menunjukkan bahwa faktor yang mempengaruhi kinerja pembelajaran adalah proses pembelajaran yang sistematis dan jelas sehingga menimbulkan kepuasan pengguna sistem. Hasil penelitian ini menunjukkan bahwa besarnya biaya tidak mempengaruhi pengaruh kepuasan terhadap kinerja pembelajaran.

Walaupun biaya tidak terbukti menurunkan kinerja pembelajaran, namun, penelitian ini menunjukkan adanya potensi besarnya biaya dapat menurunkan kinerja pembelajaran daring. Hal ini disebabkan besarnya biaya yang terjadi masih dapat diterima oleh mahasiswa. Jika biaya terlalu besar sehingga di luar kemampuan mahasiswa untuk membayar, maka akses terhadap sistem pembelajaran daring dapat terganggu. Oleh karena itu, hasil penelitian ini dapat digunakan oleh penyelenggara pendidikan untuk dapat mengembangkan konseppembelajaran yang sistematis dan jelas sesuai dengan bidang ilmu masing-masing. Selain itu, penyelenggara pembelajaran daring perlu meningkatkan kinerja sistem sehingga lebih stabil dalam mendukung proses pembelajaran dan interaksi pengajar dan mahasiswa. Penyelenggara juga perlu meningkatkan kemampuan pengajar untuk dapat memaksimalkan penggunaan teknologi, sehingga dapat berinteraksi dan memantau perkembangan siswa.

Hasil penelitian dapat memberikan kontribusi pada desain pembelajaran daring. Hasil penelitian menunjukkan proses pembelajaran dan kepuasan pengguna sistem merupakan faktor penting dalam mencapai tujuan pembelajaran. Dengan demikian beberapa hal yang dapat dilakukan dalam desain pembelajaran daring, yaitu: (1) proses pembelajaran yang jelas dan terstruktur, (2) kesesuaian materi dan metode dengan capaian pembelajaran tetap perlu diperhatikan, (3) kemudahan akses materi dan kemudahan materi untuk dipahami. Penelitian di bidang pembelajaran daring memang telah banyak dilakukan. Walaupun demikian, Hasil penelitian masih beragam dan sangat tergantung pada konteks masalah yang dihadapi. Penelitian ini juga memiliki beberapa keterbatasan, antara lain: definisi dan ukuran variabel biaya yang tidak mudah diukur. Dalam hal ini tidak ada ukuran pasti terkait dengan besaran biaya pembelajaran daring dari sisi siswa. Hal ini menyebabkan nilai yang dapatberbeda pada masing-masing orang atau pada daerah yang berbeda. Penelitian Taplin et al. (2015) yang dilakukan di luar negeri belum tentu sesuai dengan ukuran ekonomi di Indonesia. Selain itu, biaya pendidikan pada dasarnya masih ditanggung oleh orang tua, sehingga dimungkinkan faktor biaya lebih sesuai untuk responden orang tua mahasiswa. Namun, sasaran penelitian ini adalah pengguna sistem, maka mahasiswa dipilih sebagai responden. Penelitian ini dilakukan di universitas besar di Yogyakarta, sehingga daerah lain mungkin mengalami situasi yang berbeda. Oleh karena itu penelitian selanjutnya dapat menentukan dahulu besaran nilai biaya yangdapat diterima oleh mahasiswa untuk dapat digunakan sebagai tolak ukur besar kecilnya biaya. Penelitian selanjutnya dapat mengembangkan variabel persepsi kemampuan pengajar dalam menilai komponen sistem pembelajaran daring. 


\section{Daftar Pustaka}

Burgstahler, S. (1997). Teaching on the Net: What's the difference? T.H.E. Journal, 24(9), 61-64.

Bokhari, R.H. (2001). User participation and user satisfaction in information systems development. Doctoral dissertation, Brunel University, School of Information Systems, Computing and Mathematics.

Chien, T.C. (2012). Computer self-efficacy and factors influencing e-learning effectiveness. European Journal of Training and Development, 36(7), 670-686.

Chiu, C.M., Chiu, C.S., \& Chang, H.C. (2007). Examining the integrated influence of fairness and quality on learners' satisfaction and web-based learning continuance intention. Information Systems Journal, 17(3), 271-287.

Chopra, G., Madan, P., Jaisingh, P., \& Bhaskar, P. (2019). Effectiveness of e-learning portal from students' perspective A structural equation model (SEM) approach. Interactive Technology and Smart Education, 16(2), 94-116.

Dada, E. G., Alkali, A. H., \& Oyewola, D. O. (2019). An Investigation into the Effectiveness of Asynchronous and Synchronous E-learning Mode on Students' Academic Performance in National Open University (NOUN), Maiduguri Centre. Internasional Journal Modern Education and Computer Science, 5, 54-64.

DeLone, W. H., \& McLean, E. R. (2003). The DeLone and McLean model of information systems success: a ten-year update. Journal of Management Information Systems, 19(4), 9-30.

Freeze, R. D., Alshare, K. A., Lane, P. L., \& Wen, H. J. (2010). IS success model in e-learning context based on students' perceptions. Journal of Information Systems Education, 21(2), 173.

Heo, G. (2014). A study on the structural equation modeling for the effect of e-Learning. Journal of Internet Computing and Services, 15(6), 77-84.

Jang, E., Seo, Y., \& Cheong, H. (2010). The effects on course satisfaction, effectiveness awareness, and importance awareness from e-learning contents' construct factors based on demographic factors of cyber university students. Journal of Educational Technology, 20(1), 57-85.

Kim, S. S., \& Malhotra, N. K. (2005). A longitudinal model of continued IS use: an integrative view of four mechanisms underlying postadoption phenomena. Management Science, 51(5), 741-755.

Kim, H. (2011). The structural relationship between presence and the effectiveness of e-Learning in the corporate setting. (Doctoral dissertation, University of Konkuk). Retrieved from http://www.riss.kr/link?id=T11551220

Kincl, T., \& Štrach, P. (2012). Measuring website quality: asymmetric effect of user satisfaction. Behaviour \& Information Technology, 31(7), 647-657.

Kwon, Y. A., \& Noh, Y. (2015). A Study on Evaluating Learning Effects Based on Analysis of Satisfaction in E-learning. International Journal of Knowledge Content Development \& Technology, 5(2), 103-122.

Lee, O., Kim, B., \& Kim, T. (2010). The effect of computer-related characteristics on University Students' Achievement in e-Learning Courses. Journal of Korean Association for learnercentered Curriculum and instruction, 11(2), 23-44.

Liaw, S. S., \& Huang, H. M. (2013). Perceived satisfaction, perceived usefulness and interactive learning environments as predictors to self-regulation in e-learning environments. Computers and Education, 60(1), 14-24.

Lin, T. C., \& Chen, C. J. (2012). Validating the satisfaction and continuance intention of e- learning systems: combining TAM and IS success models. International Journal of Distance Education Technologies (IJDET), 10(1), 44-54.

Lin, W. S., \& Wang, C. H. (2012). Antecedences to continued intentions of adopting e-learning system in blended learning instruction: a contingency framework based on models of information system success and task-technology fit. Computers and Education, 58(1), 88-99.

Lim, B., \& Lim, J. (2004). Status and activation method of e-learning a Higher Education. Journal of Korea multimedia Society, 8(3), 16-30.

Martinez-Caro, E. (2011). Factors affecting effectiveness in e-learning: An analysis in production 
management courses. Computer Applications in Engineering Education, 19(3), 572-581.

Moon, S., \& Nam, S. (2007). A Study on the Educational Effectiveness of e-Learning. The Journal of the Korea Contents Association, 7(1), 161-168.

Park, H., \& Choi, M. (2008). Relationships Between e-learning Effectiveness and Its Related Factors in Higher Education. Journal of Educational Technology, 24(1), 27-53.

Reynolds, P. (2012), UDENTE (Universal dental E-Learning) a golden opportunity for dental education. Bulletin du Groupement International Pour la RechercheScientifique en Stomatologieet Odontologie, 50(3), 11-19.

Samarasinghe, S. M. (2012), "e-Learning systems success in an organisational context: a thesis presented in partial fulfilment of the requirements for the degree of doctor of philosophy in management information systems at Massey university, Palmerston North, New Zealand", Doctoral dissertation, Massey University.

Shneiderman, B. (2010). Designing the User Interface: strategies for Effective Human- computer Interaction, Pearson Education India, Delhi.

Simonson, M., Smaldino, S., Albright, M., and Zvacek, S. (2012). Teaching and learning at a distance: Foundations of distance education. (5th ed.). Boston: Pearson.

Singh, K. P., \& Chander, H. (2013). Professional inclination of library and information science (LIS) students of India. International Journal of Knowledge Content Development \& Technology, 3(2), 5-27.

Solihin, M., \& Ratmono, D. (2013). Analisis SEM-PLS dengan WarpPLS 3.0 Untuk Hubungan Nonlinier Dalam Penelitian Sosial dan Bisnis. Andi Publisher, Yogyakarta, Indonesia.

Somers, T. M., Nelson, K. \& Karimi, J. (2003). Confirmatory factor analysis of the end-user computing satisfaction instrument: replication within an ERP domain. Decision Sciences, 34(3), 595-621.

Tseng, M. L., Lin, R. J., \& Chen, H. P. (2011). Evaluating the effectiveness of e-learning system in uncertainty. Industrial Management and Data Systems, 111(6), 869-889.

Verdegem, P. \& Verleye, G. (2009). User-centered E-Government in practice: a comprehensive model for measuring user satisfaction, Government Information Quarterly, 26(3), 487-497.

Wei, C., Chen, N., \& Kinshuk. (2012). A model for social presence in online classrooms. Educational Technology, Research and Development, 60(3), 529-545.

www.rmoljateng.com. (2020). Anggota Dewan Turun Reses, Masyarakat Curhat Biaya Internet Besar Karena Sekolah Online.

https://www.rmoljateng.com/read/2020/08/05/29233/Anggota-Dewan-Turun-Reses,-- MasyarakatCurhat-Biaya-Internet-Besar-Karena-Sekolah-Online-. diakses 6/8/2020

Yoon, S. (2011). Verification of the predictibility of learner's motivation, teaching presence, learning flow on learning outcome in cyber university. Asian Journal of Education, 12(1). 141-166.

Zviran, M., Pliskin, N. \& Levin, R. (2005). Measuring user satisfaction and perceived usefulness in the ERP context. Journal of Computer Information Systems, 45(3), 43-52. 